\title{
TAXATION OF LIFE INSURANCE IN QUALIFIED PLANS
}

\author{
JAMES F. NASUTI*
}

I. InTRODUCTION $\ldots \ldots \ldots \ldots \ldots \ldots \ldots \ldots \ldots \ldots \ldots \ldots, 451$

II. FUndING ..................................... 454

A. Profit-Sharing Plans ...................... 454

1. The Fifty Percent Test .................... 454

2. The 100-to-1 Test ........................ 455

3. Utilization of Accumulated Trust Funds ........ 456

B. Pension Plans ................................ 457

1. Defined Benefit Pension Plans ............... 457

2. Defined Contribution Pension Plans............ 459

3. Employee Stock Ownership Plans ............ 459

C. Considerations Common to Profit-Sharing and Pension Plans ....................................... 460

1. Term Insurance .......................... 460

2. Decreasing Whole Life Policies............... 461

3. Post-Retirement Death Benefits .............. 462

4. Expenditure of Voluntary Employee Contributions

5. Limitations on Contributions .............. 463

6. Insurance on a Life Other Than That of a Participant............................... 463

III. Contributions .............................. 464

A. Treatment of Employer...................... 464

B. Taxability of the Participant $\ldots \ldots \ldots \ldots \ldots \ldots \ldots \ldots, 464$

Copyright $(1979$ by James F. Nasuti.

B.S. Duquesne University, 1970; J.D. University of Pittsburgh, 1973; LL.M. (Taxation) New York University, 1975; Member, Pennsylvania and New York bars; Adjunct Associate Professor Taxation, Drexel University. The author is with the firm of Obermayer, Rebmann, Maxwell \& Hippel, Philadelphia, Pennsylvania, and wishes to acknowledge the generous assistance of $L$. David Willison III in the preparation of this Article.

THE FOLLOWING CITATION WILL BE USED IN THIS ARTICLE:

Employee Retirement Income Security Act of 1974, Pub. L. No. 93-406, 88 Stat. 829 (codified in scattered sections of $5,18,29,31,42$ U.S.C.) [hereinafter cited by session law sections of ERISA].

All references to and quotations of Treasury Rcgulations are to the current version as amended. Citations indicate the year of original adoption. 
IV. DistRIBUtions ................................. 468

A. Non-Death Benefit Distributions ................. 468

1. Distribution of the Policy Itself ............... 468

2. Income Taxation of Retirement Benefits ........ 469

B. Gift Taxation of Transfers of Future Retirement

Benefits ...................................... 469

C. Death Benefit Distributions ...................... 470

1. Income Taxation of Death Benefits ............. 470

2. Estate Taxation of Death Benefits ............. 471

D. Coordination of Income and Estate Tax Planning for Death Benefit Distributions ...................... 472

1. Payment to the Trust ..................... 472

2. Uncertainties Concerning the Section 101(a) Exclusion .................................... 473

3. Split Payment ............................ 474

V. H.R. 10 Plans: Special Considerations ........... 475

A. Funding ................................. 475

1. Level-Premium Insurance Contracts ........... 475

2. Other Insurance Contracts ................. 476

B. Contributions.................................. 477

C. Distributions .............................. 477

1. Non-Death Benefit Distributions ............... 477

2. Gift Taxation of Transfers .................. 477

3. Death Benefit Distributions-Income Taxation... 478

4. Death Benefit Distributions-Estate Taxation .... 478

VI. Comparison BeTweEn Life INSURANCE IN A

Qualified Plan and Life Insurance In a Section 79 Plan ........................................ 478

A. Group-Term (Section 79) Insurance Generally ...... 479

B. Coverage and Nondiscrimination................. 480

C. Current Income Taxation ....................... 481

D. Income Taxation of Retirement Benefits ........... 482

E. Income Taxation of Death Benefits ............... 482

F. Estate Taxation of Death Benefits ............... 482

G. Post-Retirement Coverage and Retired Lives Reserve

$\mathrm{H} . \quad$ Life Insurance and Unincorporated Businesses...... 484

VII. OtheR ASPECTS OF LIFE INSURANCE IN QUALIFIED

Plans ....................................... 485

A. Permanent Insurance in Qualified Plans ........... 485

B. Other Considerations .......................... 486

VIII. Conclusion ............................... 487 


\section{INTRODUCTION}

Qualified pension plans exist primarily to provide retirement benefits. Qualified profit-sharing plans, which are established primarily to provide deferred compensation, are frequently used for the same purpose. Life insurance is an important consideration in this context, for it is appropriate to coordinate retirement savings and financial protection for one's dependents in the event of untimely death. Further, life insurance is one of the most flexible planning tools. It can, for example, accommodate the needs of a small enterprise with key employee insurance or the needs of a larger business with a group insurance policy. Froin the employee's point of view, life insurance in qualified plans can serve as an important estate planning device. From the employer's point of view, there can be minimal direct cost im the establishment and administration of such a life insurance plan, and the required contributions can be calculated for an extended future period. The Internal Revenue Service recognizes life imsurance as a customary inclusion in qualified plans and has established guidelines that permit the expenditure of plan assets for such insurance so long as the size of the imvestment does not conflict with the primary purpose of the plan.

Life insurance policies are of three basic types: term insurance, endowment insurance and whole life policies. ${ }^{1}$ The type of policy used determines the nature of the protection afforded the insured. The class of life insurance refers to the varieties of customers, underwriting standards or marketing methods. The three basic classes of life insurance are: ordinary insurance, industrial insurance and group imsurance. ${ }^{2} \mathrm{~A}$ brief discussion of these various types and classes of life insurance will provide some background to the uses of life imsurance in qualified plans.

Term insurance provides pure risk protection. It is a contract for a fixed period of time in which the insurer promises to pay the face amount of the policy to a third party (beneficiary) in the event of the insured's death. However, tern insurance provides no survival benefits and little or no cash. value accumulates as a savings or emergency fund for the policyholder. ${ }^{3}$ Premiums normally imcrease with the age of the applicant simce the probability of death increases. Therefore, term insurance is intended only to provide short-term protection. ${ }^{4}$ It appears

1. R. Mehr \& E. Cammack, Principles of Insurance $443-50$ (5th ed. 1972). See also R. KeETON, InSURANCE LAW 13 (1971).

2. R. MEHR \& E. CAMMACK, supra note 1, at 457.

3. Id. 443 n.2.

4. Id. 
in a variety of forms-straight, ${ }^{5}$ renewable, ${ }^{6}$ and convertible ${ }^{7}$-and is most often used by young people whose needs for protection are greater than the amount they can afford to pay for premiums on most whole life policies. ${ }^{8}$

Endowment insurance provides the beneficiary of the insured a stated amount of money in the event of the imsured's death or provides the insured the face amount of the policy in the event the imsured survives the endowment period. ${ }^{9}$ Endowment insurance is often viewed as a savings account with life insurance protection. Premiums for such policies are comparatively high. "The high premium rate ineans that the amount of deatlu protection that can be purchased . . . [is] less than usually is considered reasonable for the typical family. Therefore, endowment insurance is not recommended unless the need for death protection is secondary," 10 as is frequently the case when insurance is purchased in a qualified plan.

The inore frequently used policy is the whole life policy, smce it is designed to provide resources after death, regardless of when the insured dies. ${ }^{11}$ It is often used as a savings plan for the accumulation of caslı values. ${ }^{12}$ The most common plan of whole life insurance is the ordinary life policy (also called straight life or continuous-premiunn) under which the insured pays the same yearly amount for as long as the policy remaims in force. An ordinary life contract consists of a term imsurance element that declines over the period of the contract, ulti-

5. Straight term insurance automatically terminates at the end of some designated period. The period of coverage is usually five, ten or twenty years. Id. 443 .

6. Renewable term insurance provides an option to the insured to renew the policy before its expiration date without regard to health at the time of exercising the option or otherwise demonstratimg insurability. Options vary and nay limit the number of renewals or provide an option only until the insured lias reached a specific age. Id. See also R. KeEton, supra note 1, at 14.

7. Convertible insurance provides the insured with an option to change the term insurance, during a specific period of time, to endownent or whole life policies without evidence of insurability. R. Mehr \& E. CAMmaCK, supra note 1, at 443-44. See also R. Keeton, supra note 1, at 14.

8. R. Mehr \& E. Cammack, supra note 1, at 446.

9. Id. 447 .

10. $I d$.

11. Id. 449.

12. There are three basic forms of premium payments-single-premium plan, limited-payment plan, or continuous-premium plan. Id. 448.

The single-premium plan involves the payment of a relatively large sum at the issuance of the policy. The payment must be large enough so that it, together with interest to be earned on its investment, will be large enough for the insurer to honor all obligations under the contract without the necessity of any further premium payments. . . .

The limited-payment plan is an arrangeinent whereby the insured continues to pay premiums for a certain period of years, after which time no further preımim payments need be made.

Id. 448-49. 
inately reaching zero, and an investment element that starts out small and, through additional contributions and earnings, ultimately reaches or exceeds the face alnount of the contract. The two elements, taken together, result in the insured always being certain of receiving no less than the face anount of the contract. Thus, an ordinary whole life policy is the basic insurance coverage and the coverage inost appropriate in the great nnajority of cases because it combines, in moderation, the savings features of an endowment pohicy with the risk protection of a term policy. ${ }^{13}$

The various classes of life insurance are distimguishable on the basis of "type of customers, policy amounts, availability of cash surrender values, inethods of computing and collecting premiums, underwriting standards, and marketing methods." 14 As alluded to in the above discussion, ordinary insurance is the nnost common class of life insurance. It is usually issued in amounts of $\$ 1000$ or more, may be mass-marketed or sold wholesale, and represents over half of all life insurance in force in the United States today. ${ }^{15}$ Industrial life insurance, on the other hand, is usually written with face amounts less than $\$ 1000$, with premiums payable in less than monthly intervals, and collected at the houne. ${ }^{16}$ Today industrial life insurance represents less than three percent of all policies. ${ }^{17}$ Finally, group life insurance is issued under a inaster policy to a group of persons without requiring a medical examination. ${ }^{18}$ Group life insurance represents about forty-four percent of all policies and is the class most often purchased by qualified plans. ${ }^{19}$

This Article will examine the funding restrictions applicable to the various types of policies; will explain the current tax effects to the employer and employee of the use of contributions in this way; and will analyze the tax consequences of, and income and estate plan for, the receipt of life insurance benefits. Primary emphasis is on the tax aspects of funding qualified plans with whole life or endownent insurance, whether in ordinary form or otherwise. Except as noted, the general rules normally apply to the many variations on these types of policies. Funding a qualified plan with pure term insurance will receive separate consideration. Finally, for purposes of comparison, the purchase of group-term insurance outside of a qualificd plan will be analyzed in-depth.
13. Id. 450.
14. Id. 457.
15. Id. $457-58$.
16. Id. 459.
17. Id.
18. Id.
19. Id. 460 . 


\section{FUNDING}

The Internal Revenue Code and the regulations thereunder provide complex limitations concerning the extent to which a qualified plan may be funded with life insurance. The general limitation, from which all others arise, concerns the purpose of the plan. A qualified pension or annuity plan is one established primarily to provide retirement benefits, and a qualified profit-sharing plan is one established primarily to provide deferred compensation. In each case the provision of death benefits, either through insurance or otherwise, may only be incidental to the primary purpose of the plan. Therefore, a plan that provides only such benefits as are afforded through the purchase of ordinary hife contracts, or that is operated for the primary purpose of providing life insurance protection, will not qualify. ${ }^{20}$ How inuch insurance protection is incidental, and therefore permissible, depends on whether the plan is a profit-sharing plan, a defined benefit pension plan or a defined contribution (inoney purchase) pension plan. ${ }^{21}$

\section{A. Profit-Sharing Plans.}

"A profit-sharing plan . . . is primarily a plan of deferred compensation, but the ainounts allocated to the account of a participant may be used to provide for him or his family incidental life . . . insurance."22 An investunent in ordmary (whole) life insurance is deemed incidental if it meets either the fifty percent test or the 100-to-1 test.

1. The Fifty Percent Test. In Revenue Ruling $73-501^{23}$ a profitsharing plan was found to provide only incidental life insurance protection. First, less than fifty percent of the employer contributions credited to each participant's account were used to purchase ordinary life insur-

20. Rev. Rul. 54-67, 1954-1 C.B. 149 (pension plans); Special Rulings, Aug. 1, 1952, [1953] Stand. Fed. Tax Rep. (CCH) | 6107; Special Rulings, Oct. 7, 1952, [1953] STand. Fed. TAX REP. (CCH) $₫ 6108$ (profit-sharing plans).

21. See generally Chan, How Much Life Insurance Protection Can a Qualified Plan Provide for Employees?, 17 TAx. For Accountants 226 (1976).

22. Treas. Reg. \$ 1.401-1(b)(1)(ii) (1956).

A profit-sharing plan is a plan established and maintained by an employer to provide for the participation in his profits by his employees or their beneficiaries. The plan must provide a definite predetermined formula for allocating the contributions made to the plan anong the participants and for distributing the funds accumulated under the plan after a fixed number of years, the attainment of a stated age, or upon the prior occurrence of some event such as layoff, illness, disability, retirement, death or severance of employment. . . . A profit-sharing plan within the meaning of section 401 is primarily a plan of deferred compensation, but the amounts allocated to the account of a participant may be used to provide for him or his family incidental life or accident or Td. health insurance.

23. 1973-2 C.B. 127, clarified and modified by Rev. Rul. 74-307, 1974-2 C.B. 126. 
ance policies on the participant's life. Second, upon reaching age 65 , or upon prior termination of employment other than by death, the policies were to be converted into cash that was to be distributed, together with the participant's account balance, in a lump sum. In the event of the employee's death prior to age 65 , the amount credited to his account at that time plus the face value of the insurance policies on his life was to be paid to his designated beneficiary as a pre-retirement deatl benefit.

For the purposes of this test, fifty percent of employer contributions is determined by totaling contributions and forfeitures allocated to the account of the employee. Earnings and capital gains and losses of the trust fund are not taken into account. ${ }^{24}$ In computing the cost of insurance, the aggregate amount of the actual premiums paid is to be used rather than a table of rates that merely refiects the net cost of pure life insurance. ${ }^{25}$

Under the facts in Revenue Ruling 73-501, upon reaching age 65 or prior termination of employment other than by death the policies are to be converted into cash and distributed. However, the program of current life insurance protection "may be contimued after normal retirement date, during the period of continued employment of a participant who elects not to retire," provided that the fifty percent test continues to be met. ${ }^{26}$

2. The 100-to-1 Test. In Raymond J. Moore ${ }^{27}$ the Board of Tax Appeals established the principle that a qualified pension plan can provide incidental life insurance protection. The amount of the life imsurance protection in that case equaled 100 times the projected monthly benefit at retirement. ${ }^{28}$ Revenue Ruling $60-83^{29}$ relied upon Moore to hold that

in a level premium retirement income contract providing for the accumulation of a fund sufficient to pay a life annuity of $\$ 10$ per month upon attainment of age 65 years, with a death benefit before retirement equal to $\$ 1,000$ (for each $\$ 10$ of retirement imcoine) or the cash

24. Rev. Rul. 57-213, 1957-1 C.B. 157, amplifying Rev. Rul. 54-51, 1954-1 C.B. 147.

25. Rev. Rul. 66-143, 1966-1 C.B. 79, clarified by Rev. Rul, 68-31, 1968-1 C.B. 151. The currently applicable tables of rates reflecting the new cost of pure life insurance are commonly referred to as the "Table l" and "P.S. 58" values. See text accompanying uotes 97-103 infra.

26. Rev. Rnl. 57-213, supra note 24 , at 158 . It would appear that the same would be true if, in the alternative, the 100-to-1 test continues to be met.

27. 45 B.T.A. 1073 (1941), acq. 1943 C.B. 17.

28. See also Simmons v. United States, 334 F. Supp. 853 (W.D. Tenn. 1971), in which life insurance protection equal to approximately 150 times the projected monthly retirement beneft was held not incidental.

29. 1960-1 C.B. 157. 
value if greater, the life insurance element is considered "incidental" to the purpose of accumulating funds for distribution at retirement age, and purchase of such contracts under a profit-sharing plan is acceptable. ${ }^{30}$

Thus, the investment by a profit-sharing plan in retirement mcome contracts or paid-up units of endowment insurance with a pre-retirement death benefit of no more than 100 times the monthly annuity at retirement, or the cash value if greater, complies with the requirement that life insurance protection be incidental.

Apphication of the 100-to-1 test may be more complex where, in addition to retirement income contracts and paid-up units of endowment imsurance, a profit-sharing plan also establishes an auxiliary fund with a separate account for each participant. Although there is no authority addressing this issue, it would appear that the test applicable to pension plans ${ }^{31}$ would apply, in that the policy considerations are the saine.

3. Utilization of Accumulated Trust Funds. Both pension and profit-sharing plans are frequently thought of as retirement plans, primarily because benefits are norinally not distributed until retirement. However, benefit distribution at retirement is required only of pension plans, ${ }^{32}$ a profit-sharing plan need only be one of deferred compensation. ${ }^{33}$ According to Revenue Ruling 71-295, ${ }^{34}$ " $[t]$ he tern 'fixed number of years' is considered to mean at least two years"; ${ }^{35}$ therefore, all or part of the funds in a profit-sharing plan may be distributed after they have been held or accumulated for at least two years.

The use of trust funds for a current benefit, such as the purchase of life, accident or health insurance, is deemed to constitute a current distribution from the plan. ${ }^{36}$ Simce all amounts that have been accumulated for two or nnore years may be currently distributed, there is no limitation on the amount of such accunnulated funds that inay be expended for insurance protection. ${ }^{37}$

30. Id. 158.

31. See text accompanying notes $43-47$ infra.

32. Treas. Reg. $\$ 1.401-1(b)(1)(i)$ (1956).

33. Treas. Reg. $\$ 1.401-1$ (b)(1)(ii) (1956). A profit-sharing plan "must provide a definite predetermined formula ... for distributing the funds accumulated under the plan after a fixed number of years, the attainment of a stated age, or upon the prior occurrence of some event ...." Id.

34. 1971-2 C.B. 184, superseding Rev. Rul. 54-231, 1954-1 C.B. 150.

35. Id.

36. Rev. Rul. 60-83, 1960-1 C.B. 157.

37. Rev. Rul. 61-164, 1961-2 C.B. 99, 100. 


\section{B. Pension Plans.}

A pension plan is a plan estabhished primarily to provide systematically for the payment of definitely determinable benefits after retirement, but it may also provide for the payment of incidental death benefits through insurance or otherwise. ${ }^{38}$ As with respect to profitsharing plans, the applicable limitation is that life insurance benefits must be "incidental." Since pension plans may not normally begin distributions until retirement, they have no special discretion, as do profitsharing plans, to expend funds that have been accumulated for two years or more.

There are two basic types of pension plans: defined (or fixed) benefit plans ${ }^{39}$ and defined contribution plans. ${ }^{40}$ Under a defined benefit plan the employer is required to contribute such amounts, determined on an actuarially sound basis, as will enable the plan to provide specifically prescribed plan benefits, usually in the form of an annuity, at retirement. ${ }^{41}$ Under a defined contribution plan the employer is committed to contribute a certain specifically determinable amount (usually a percentage of salary) each year for the benefit of each participant. ${ }^{42}$

1. Defined Benefit Pension Plans. Life insurance funding of a defined benefit pension plan will be deemed incidental if either the fifty percent test or the 100-to-1 test is compled with. ${ }^{43}$ Apphication of these tests is somewhat complicated if the death benefit is payable not only from the proceeds or face ainount of the pohcy, but also from an amount credited to the participant's account in an auxiliary fund. ${ }^{44}$

38. Treas. Reg. $\S 1.401-1$ (b)(1)(i) (1956).

A pension plan within the meaning of section 401(a) is a plan established and maintained by an employer primarily to provide systematically for the payment of definitely determinable benefits to his employees over a period of years, usually for life, after retirement. Retirement benefits generally are measured by, and based on, such factors as years of service and compensation received by the employees. The determination of the amount of retirement benefits and the contributions to provide such benefits are not dependent upon profits. . . . A pension plan may provide for the payment of a pension due to disability and may also provide for the payment of incidental death benefits Id. through insurance or otherwise.

39. ERISA § 1002(35) (codified at I.R.C. § 414(j)).

40. ERISA § 1002(34) (codified at I.R.C. § 414(i)).

41. See, e.g., 3 S. Young, Pension and Profit-Sharing Plans $\$ 10.01$ (1978).

42. $I d$.

43. Rev. Rul. 74-307, 1974-2 C.B. 126, clarifying and modifying Rev. Ruls. 73-501, 1973-2 C.B. 127; 68-453, 1968-2 C.B. 163. Both of these tests are discussed above in the context of profitsharing plans. See text accoinpanying notes 23-31 supra.

44. See, e.g., Rev. Rul. 68-453, 1968-2 C.B. 163 (cash value of insurance contracts at normal retirement age was to be used for participant's normal retirement benefit-auxiliary fund to provide balance). 
Such a mechamism is referred to as a "split funded" plan; a reference to the fact that the plan is funded both by assets held by the trustee and by investments in life insurance contracts.

After first taking a position to the contrary, the Internal Revenue Service concluded that death benefits would be deemed incidental if the fifty percent test is met "even if the total death benefit consists of both the face amount of the policies and the amount credited to the participant's account [in the auxiliary fund] at the time of deatl ...."45 In the alternative, a pre-retirement death benefit would also be considered incidental if the total death benefit "is equal to the greater of (a) the proceeds of ordinary life insurance policies providing a death benefit of 100 times the anticipated inonthly normal retirement benefit or (b) the sum of (i) the reserve under the ordinary life insurance policies plus (ii) the participant's account in the auxiliary fund." 46 However, "a death benefit equal to the sum of the proceeds of the ordinary life insurance contracts plus the amount of the employee's account in the auxiliary fund would exceed the death benefit under a typical level premium retirement income contract witl a face amount of 100 times the anticipated monthly retirement benefit, and would not be incidental' . . ."47 Thus, in a split-funded plan, the fifty percent test, but not the 100-to-1 test, can be applied without regard to amounts accuinulated in an auxiliary fund.

If a deatlı benefit is payable to the employee's spouse in the form of a straight life annuity im an amount that is either a percentage of the portion of the employee's normal retirement benefit accrued on account of credited service up to the date of death, or that is a percentage of the employee's anticipated normal retirement benefit assuming contimuation of service to that date at the rate of compensation in effect at the time of death, then whether the death benefit is incidental depends on the percentage used. Revenue Ruling $70-611^{48}$ sets forth a table containing the maximum permissible percentages, which vary with the age of the employee at death. ${ }^{49}$ For example, in the case of a pension plan providimg for the payinent of a spouse's benefit for life beginning immediately upon the death of the employee if the employee dies after reaching age thirty, the maximum benefit that will be considered incidental in accordance with that table would be eighty percent of the

45. Rev. Rul. 74-307, supra note 43.

46. Id.

47. Rev. Rul. 68-453, 1968-2 C.B. 163, 164, clarified and modified by Rev. Rul. 74-307, 1974-2

C.B. 126.

48. $1970-2$ C.B. $89,90$.

49. Id. 90 . 
employee's accrued benefit or fifty-five percent of the employee's anticipated normal retirement benefit.

2. Defined Contribution Pension Plans. A defined contribution (money purchase) pension plan $^{50}$ may provide life insurance benefits that are deemed "imcidental" by meetimg the limitations applicable to eitller profit-sharing plans ${ }^{51}$ or defined benefit pension plans. ${ }^{52}$ In the event that sucl1 a plan provides insurance protection only for insurable participants it will not be considered discriminatory provided that contributions for combimed msurance and annuity benefits for insurable participants are equal to contributions made for annuity benefits for uninsurable participants. ${ }^{53}$

3. Employee Stock Ownership Plans. An employee stock ownership plan (ESOP) is a defined contribution plan designed to mvest primarily in "qualifying employer securities"; 54 life insurance is not a qualifying employer security. ${ }^{55}$ Incidental benefits such as life insurance can be provided by an ESOP as long as the premium expenditure does not exceed twenty-five percent of employer contributions. ${ }^{56}$ However, under certain circumstances an ESOP is permitted to borrow from or on the strength of the credit of a disqualificd person, ${ }^{57}$ that is, a person who has a fiduciary relationship to the plan or trust or who is related to the employer. ${ }^{58}$ Sucl a loan is referred to as an "exempt loan."59 Generally, an ESOP is subject to the same limitations concerning the investment im life insurance contracts as are other defined contribution plans. However, no such investment may be made with the proceeds of an exempt loan. ${ }^{60}$

In the case of a small or moderately-sized corporation to which

50. A money purchase plan is considered a pension plan because of the fixed obligation of the employer to make contributions. See Rev. Rul. 73-379, 1973-2 C.B. 124 (plan disqualified which gave board of directors discretion to limit the amount of employer contributions on behalf of employees who own more than $10 \%$ of the employer's stock).

51. Rev. Rul. 66-143, 1966-1 C.B. 79, clarified by Rev. Rul. 68-31, 1968-1 C.B. 151. See also Rev. Rul. 69-421, part 2(n)(1), 1969-2 C.B. 59, 67.

52. Rev. Rul. 74-307, 1974-2 C.B. 126.

53. Rev. Rul. 68-245, 1968-1 C.B. 160.

54. I.R.C. $\$ 4975(\mathrm{e})(7)(A)$. An "employer security" is a security issued by an employer of employees covered by the plan, see ERISA $\$ 1107$ (d)(7), or by an affiliate of such employee. ERISA $\S 1107$ (d)(1). A qualifying employer security is an employer security which is stock or a marketable obligation. See ERISA $\$ \$ 1107(\mathrm{~d})(5),(\mathrm{e})$.

55. ERISA \& 1108(b)(5).

56. I.R.C. $\$ 4975(\mathrm{~d})(3)$. See Proposed Reg. $\$ 54.4975-11(\mathrm{~b})(2)(\ddot{i})$.

57. I.R.C. $\$ 4975(d)(3)$.

58. I.R.C. $\$ 4975(\mathrm{e})(2)$.

59. Treas. Reg. $\$ 54.4975-7$ (b)(1)(iii) (1977).

60. Treas. Reg. \$ 54.4975-7(b)(4) (1977). 
one or a few employees are very important, an ESOP would be a likely candidate for key person insurance ${ }^{61}$ in order to protect the value of its principal asset, its stock in the corporation. In fact, having the plan purchase key-person insurance provides a deduction for premium payments that would be unavailable if the corporation purchased the imsurance. ${ }^{62}$ Such an imvestment would be permissible provided that it is not imprudent and is not a prohibited transaction for the benefit of a shareholder-employee. ${ }^{63}$

\section{Considerations Common to Profit-Sharing and Pension Plans.}

The limitations applicable to profit-sharing plans, defined benefit pension plans and defined contribution pension plans have evolved concurrently, but separately. The lines of authority for the apphication of the different tests to the different types of plans are found in different Revenue Rulings, and the tests are sometimes stated somewhat differently. The fifty percent test is applicable identically to all three types of plans. Applicability of the 100-to-1 test is also identical so long as an auxiliary fund is not involved. ${ }^{64}$ In the event that such a fund is involved, it is not certain how a profit-sharing plan is to comply with the 100-to-1 test, but the rules applicable to pension plans may apply in this case also.

1. Term Insurance. The requirement that life insurance funding of qualified plans be "incidental" is nost appropriately applied to the funding of plans with pure tern insurance. The regulations provide that a qualified pension or profit-sharing plan may not be a temporary program. ${ }^{65}$ And, as noted earher, ${ }^{66}$ pure risk insurance for a five, ten or

61. Key person insurance is a type of business insurance "designed to protect the business against the financial loss that occurs when a key employee is lost by disability or death. . . Usually the policies-life and disability income - are taken out by the company, owned by the company, and the premiums are paid by the company." R. MEHR \& E. CAMMACK, supra note 1, at 568. Generally, the premiums paid by the company are not a tax deductible expense, and the proceeds, which are made payable to the company, are not includable in taxable income. $I d$.

62. I.R.C. $\$ 264$. But see Proposed Reg. \$ 54.4975-11(b)(2)(ii) (restrictions on the purchase of key person insurance).

63. See Rock \& Haley, New, More Liberal Regulations Clarify the Status of ESOPs in Many Vital Respects, 47 J. TAX. 354, 355 (1977). See also Rev. Proc. 75-48, § 3.05(4), 1975-2 C.B. 583.

64. Rev. Ruls. 74-307, 1974-2 C.B. 126; 73-501, 1973-2 C.B. 127.

65. Treas. Reg. § 1.401-1(b)(2) (1956).

The term "plan" implies a permanent as distinguished from a temporary program. Thus, although the employer may reserve the right to change or terminate the plan, and to discontinue contributions thereunder, the abandonment of the plan for any reason other than business necessity within a fcw years after it has taken effect will be evidence that the plan from its inception was not a bona fide program for the exclusive benefit of Id. einployees in general.

66. See text accompanying note 3 supra. 
twenty year period results in little casl value attributable to the policy. Thus, if a plan were funded entirely by such insurance, the plan might be viewed as only a temporary one since once the pure risk insurance has expired, no value remains in the plan.

The question of whether insurance benefits are incidental is to be answered by reference to the amount that is deemed to be currently distributed with respect to those benefits. Revenue Ruling 73-50167 found that when trust funds are used "to pay the cost of life, accident, or health imsurance for an employee"68 they are distributions that will be deeined incidental

if, in the aggregate, they do not exceed 25 percent of the current contributions, allocated to a participant's account, that have been accumulated less than two years.... .

In the case of ordinary life insurance policies, less than 50 percent of such contributions may be used to pay premiums simce only approximately half of these premiums are used for pure insurance protection. Thus, the 50 percent limitation on the purchase of ordinary life insurance policies is consistent with the 25 percent limit on the cost of pure insurance protection. ${ }^{69}$

Therefore, the fifty percent test has its origin in the assumption that if fifty percent of contributions are used to pay premiums on ordinary life insurance, only about one-lialf of those premiums are expended for pure insurance protection. It would follow, therefore, that twenty-five percent of the contribution $s^{70}$ may be used to purchase term insurance which does, in fact, constitute pure insurance protection. ${ }^{71}$

Althougl Revenue Ruling 73-501 involved a profit-sharing plan, Revenue Ruling 74-30772 relied on its " 50 percent contribution" and " 25 percent cost" analysis to extend the fifty percent test to all types of pension plans. ${ }^{73}$ Accordingly, it would appear that with respect to either pension or profit-slaring plans, twenty-five percent of contributions may be used to purcliase term insurance.

\section{Decreasing Whole Life Policies. ${ }^{74}$ As to both profit-sharing}

67. 1973-2 C.B. 128.

68. Id.

69. Id. See also Rev. Rul. 61-164, 1961-2 C.B. 99.

70. Total contributions would be determined in the same way as under the $50 \%$ test. See text accompanying note 24 supra.

71. But see Simmons, Insurance in Employee Compensation Arrangements, 2 ALI-ABA CourSE MATERIALS J. 9 (1978), suggesting that term insurance may not satisfy the $50 \%$ test because of its lack of cash value. Id. 22.

72. 1974-2 C.B. 126.

73. Id. 127.

74. A decreasing whole life policy is one which provides for an amount of insurance which 
plans and defined contribution pension plans, the fifty percent test is inapplicable to a decreasing whole life policy with level premiums. The ratio of the pure insurance eleinent to the investinent element in sucl a policy is larger than in an ordinary policy; as a result, no more than twenty-five percent of the funds allocated to a participant's account may be expended for premiums on this type of policy. ${ }^{75}$

3. Post-Retirement Death Benefits. In Revenue Ruling $60-59^{76}$ the Internal Revenue Service approved a pension plan providing a post-retirement death benefit that was equal to fifty percent of annual salary in effect for the year preceding the einployee's retirement, and that cost less than ten percent of the cost of the pension plan. The benefit was found to be "incidental," whether provided by insurance or otherwise, although the standard by reference to which this was determined was unstated. Revenue Ruling 60-59 distimguished Revenue Ruling $56-656,{ }^{77}$ which held that any pension or profit-sharing plan that permitted an employee to irrevocably elect, prior to retirement, to lave all or part of his nonforfeitable interest paid only to his designated beneficiary after his death, was not a qualified plan.

While Revenue Ruling 60-59 does not apply to profit-sharing plans, such plans are not restricted as to the imvestment in insurance of funds accumulated for two or more years. As post-retirement death benefits are likely to be purchased with such funds, profit-sharing plans are, in effect, not restricted with respect to the provision of such benefits.

4. Expenditure of Voluntary Employee Contributions. In the case of both profit-sharing and pension plans, Revenue Ruling 69-408 ${ }^{78}$ holds that voluntary employee contributions, but apparently not the earnings thereon, may be used to purchase life insurance (either whole life or tern) without regard to the otherwise applicable restrietions. The Ruling gives no rationale for its conclusion, and therefore does not indicate whether the same holding would result if involuntary (that is, mandatory) employee contributions were used for this purpose. Simce such contributions are not deductible and thus do not give rise to a current tax benefit, the same resnlt should obtain.

declines with the passage of time (for example, a $\$ 10,000$ policy which decreases by $\$ 1,000$ per year for five years, and then remains constant at $\$ 5,000$ ).

75. Rev. Rul. 76-353, 1976-2 C.B. 112. As to increasing death benefit whole life insurance, see Private Letter Ruling 7916065.

76. 1960-1 C.B. 154.

77. $1956-2$ C.B. 280.

78. $1969-2$ C.B. 58 . 
In Revenue Ruling 70-36979 the qualification of a noncontributory profit-sharing plan providing incidental life insurance protection was found to be not adversely affected by an amendment to discontinue einployer contributions and permit employees to make contributions to keep the insurance contracts in force.

5. Limitations on Contributions. Contributions and other additions with respect to a participant for any one year are subject to the limitations of section 415 . In the case of a defined contribution plan, including inoney purchase pension plans and all profit-sharing plans, the limitation is determined by reference to the "annual addition," which "Ineans the sum for any year of-(A) employer contributions, (B) the lesser of-(i) the amount of the employee contributions in excess of 6 percent of his coinpensation, or (ii) one-half of the einployee contributions, and (C) forfeitures." ${ }^{80}$ For such a plan, the annual addition is limited to the lesser of (1) twenty-five percent of the participant's coinpensation or (2) $\$ 25,000$, adjusted for post-1974 increases in the cost of living in accordance with section $415(\mathrm{~d}) .{ }^{81}$ Therefore, in the case of profit-sharing plans and defined contribution pension plans, einployee contributions utilized to acquire life insurance, together with other einployee contributions, are limited by section 415 (c). Since the portion of einployer contributions that may be used to purchase life insurance is itself expressed as a percentage of employer contributions, the section 415 (c) limitation is only indirectly relevant to the expenditure of such contributions.

Under section 415(b), the applicable limitation for defined benefit plans is written in teruns of the actuarial equivalent of a straight life annuity without regard to ancillary benefits not directly related to retireinent incoine benefits. This formula does not appear to take into account death benefits, and therefore does not appear to limit the expenditure of contributions for such benefits.

6. Insurance on a Life Other Than That of Participant. In Revenue Ruling $69-523^{82}$ a pension plan that permitted a participant to invest a portion of contributions on his behalf in insurance on the life of anyone in whoin he had an insurable interest was disqualified on the ground that this is a benefit "not custornarily imcluded in a pension plan." Presumably, the result would be the same even if only voluntary

79. $1970-2$ C.B. 84 .

80. I.R.C. $\S 415(\mathrm{c})(2)$.

81. I.R.C. $\$ 415(c)(1)$.

82. $1969-2$ C.B. 90 . 
employee contributions were so used.

While Revenue Ruling 69-523 does not distinguish between defined benefit and defined contribution pension plans, and is therefore apparently apphicable to both, its relevance to profit-sharing plans is not specified. It could reasonably be said that this sort of benefit is also not custornarily provided by profit-sharing plans and, therefore, such plans would be similarly disqualified. Arguably, this restriction would not apply to amounts that have been accumulated by a profit-sharing plan for at least two years.

\section{Contributions}

\section{A. Treatment of the Employer.}

An einployer nornally is treated no differently with respect to contributions that are to be used to purchase life insurance than with respect to other contributions to a qualified plan. However, an exception to this rule applies if upon the death of the employee the insurance benefits are to be paid to the trustee, who is to apply such proceeds to the payment of subsequent premiums on behalf of other einployees. Revenue Ruling $55-748^{83}$ held that

[t]hat part of the employer's contributions attributable to the purchasing of life insurance benefits ... which, when they become payable, are applicable to the reduction of subsequent employer contributions to the plan may not be considered as a cost of the . . . plan for the purpose of determining the limitation on deductions . . . for the year in which such contributions are paid, and may not be deducted as such. ${ }^{84}$

Such contributions are deemed to be advance funding. While not currently deductible, they may be deducted in subsequent years to the extent provided im section 404(a)(1)(D), subject to the limitations applicable to such subsequent years. It is unclear whether the fact that such contributions constitute currently nondeductible advance funding means that they need not be taken into account towards the limitations discussed above concerning the extent to which a plan inay be funded with life insurance.

\section{B. Taxability of the Participant.}

Just as employer contributions expended for insurance on the life of a participant are treated as current distributions for purposes of determining whether a pension or profit-sharing plan is qualified, so also

83. 1955-2 C.B. 234.

84. Id. 235. See also Private Letter Ruling 7910064. 
are such expenditures treated as current distributions for purposes of income taxation of the participant. This is true whether or not the plan is trusted, and without regard to the type of life imsurance purchased, so long as the proceeds of the contract are payable either directly or indirectly to the participant or to a beneficiary of the participant. ${ }^{85}$

"Any contribution to a plan . . . which is allowed as a deduction ... and any mcome of a [qualified] trust . . . which is determined . . . to have been applied to purchase . . . life insurance protection . . . is includable in the gross imcome of the participant for the taxable year when so applied." 86 This rule is applicable even if the participant's interest in the insurance contract is forfeitable prior to death. ${ }^{87}$ It does not apply, however, "if the trust has a right under any circumstances to retain any part of the proceeds of the life insurance contract." 88 Thus, no participant would be currently taxable if the trust were to purchase key person insurance as an investment or a group indemnity policy to protect the trust agamst excessive death benefit payouts. ${ }^{89}$

In Revenue Ruling $69-544^{90}$ the participant was currently taxable on life insurance protection provided by a qualified plan despite the fact that his interest in the benefits was forfeitable. Furthermore, if his einployment "terminated as a result of his dishonesty, fraud, gross neglect of duty, or intentional damage to the employer's property,"91 any insurance contract held for him would become the trust's property. The Ruling held that

[a]s used in section 1.72-16(b)(6) of the regulations, the trust's right to retain any part of the proceeds of the life insurance under the contract means a present right as a named beneficiary to receive the life insurance proceeds. In this case the trust does not have a present right as a named beneficiary to receive the proceeds of the contract and there is no basis for overriding the specific provisions of section 72(m)(3) of the Code. .2

Revenue Ruling 69-544 thus goes beyond the literal meaning of regulations section $1.72-16(b)(6)$, and its rationale would be equally applicable even if the benefit were forfeitable upon the happening of a more likely occurrence, such as termination of employment prior to complete vesting. (Under current law forfeiture may only occur upon death or

85. Treas. Reg. § 1.72-16(b) (1963).

86. I.R.C. § 72(m)(3)(B). See also Treas. Reg. § 1.72-16(b)(3) (1963).

87. Rev. Rul. 69-544, 1969-2 C.B. 12.

88. Treas. Reg. \& 1.72-16(b)(6) (1963).

89. Rev. Rul. 66-138, 1966-1 C.B. 25.

90. 1969-2 C.B. 12.

91. $1 d$.

92. Id. 
upon the termination of employment prior to complete vestimg.) $)^{93}$ In both cases the trust would have a right under some circumstances to retain a part of the proceeds of the life insurance contract. Nonetheless, Revenue Ruling 69-544 would seem to be a correct interpretation of section 72(1n)(3) with respect to the facts described there, or in any case where death results in full vestimg. In such situations the possibility of forfeiture of the life insurance benefit is illusory; that is, in the event of death prior to forfeiture, death itself negates the possibility of forfeiture, and in the event of death subsequent to forfeiture, forfeiture itself terminates the current taxability of the participant and thus preserves the statutory symmetry. In Funkhouser $v$. Commissioner ${ }^{94}$ the Tax Court reached this conclusion with respect to a fact pattern substantially similar to that in Revenue Ruling 69-544, holding that a contrary interpretation would bring the regulations under section 1.72$16(b)(6)$ into conflict with "the scheme of the statute."95 It is arguable, however, that Revenue Ruling 69-544 would not be applicable in the event that death itself would result im a forfeiture of life imsurance benefits, as where partial vesting will not become full vesting upon death. In this case regulations section 1.72-16(b)(6) would be both literally and substantively applicable, and the participant might reasonably assert that the prospect of forfeiture even in the event of death ought to preclude current taxability. ${ }^{96}$

In computing the participant's current income, the amount of pure insurance protection-that is, the excess of the amount payable upon death at any time during the year over the cash value of the policy at the end of the year-is considered current life insurance protection. The cost of this protection is included in the gross income of the participant for the taxable year in which contributions or earnings are apphed for this purpose. ${ }^{97}$

The amount required to be included in the participant's income is determined pursuant to a table found in Revenue Ruling $55-747,{ }^{98}$ generally known as the "P.S. 58 cost"-a reference to the document in

93. I.R.C. § 41 (a) (originally enacted as ERISA, Pub. L. No. 93-406, § 1012(a), 88 Stat. 829, 901).

94. 58 T.C. 940 (1972). See also Goldsmith v. United States, 586 F.2d 810 (Ct. Cl. 1978), which reached the same result with respect to a nonqualified deferred compensation plan under which benefits were partially forfeitable in the event of termination of enployment prior to retirement, but were fully vested in the event of death.

95. 58 T.C. at 948.

96. Treas. Reg. § 1.72-16(b)(3) (1963).

97. I.R.C. $\& 72(\mathrm{~m})(3)(\mathrm{B})$.

98. 1955-2 C.B. 228. Rev. Rul. 55-747 covers ages 15 through 75; the table was extended through age 81 by Rev. Rul. 66-110, 1966-1 C.B. 12. 
which the table was originally proinulgated. ${ }^{99}$ In the event that the insurer's current published premiun rates for individual one-year term life insurance available to all standard risks are lower than the P.S. 58 cost, the lower rates may be used ${ }^{100}$ provided that they are the rates charged for initial issue insurance and are not dividend option rates, ${ }^{101}$ such as those applicable to the fifth dividend option. ${ }^{102}$ The rates set forth in regulations section 1.79-3(d)(2), Table I (Table I rates), which prescribe the amount includible in the income of an employee with respect to employer-provided group-term life insurance coverage in excess of the $\$ 50,000$ of such coverage eligible for exclusion under section 79 , may not be utilized. ${ }^{103}$ Furthermore, no part of the imsurance coverage qualifies for the benefits of section 79.104 The amount included in the income of the participant represents a personal, nondeductible expense. ${ }^{105}$ However, it does appear to constitute personal service income for purposes of the inaximuin $\operatorname{tax}^{106}$ and incoine tax withholding is not required. ${ }^{107}$

Utilization of contributions to purchase insurance protection gives rise to income to the employee only when employer contributions or trust incoine is so used. Use of employee contributions that do not yield a deduction when made does not result in income to the employee. ${ }^{108}$ A plan may specify whether einployer or employee contributions are to be used for this purpose but, in the absence of such a specification, employer contributions and trust income will be considered to have been used before einployee contributions. ${ }^{109}$

99. Id. (P.S. No. 58, Revised, issued on Mar. 7, 1947).

100. Rev. Rul. 66-110, 1966-1 C.B. 12, 14.

101. A "dividend option" is a right, exercisable by the owner of the policy, to have all or some of the dividends on the policy applied to the purcliase of additional insurance, usually at special rates. Under a "fifth dividend option" every fifth dividend is so applied.

102. Rev. Rul. 67-154, 1967-1 C.B. 11.

103. Treas. Reg. $\$ \S 1.79-1(a),-3(d)(3)$ (1966). The P.S. 58 rates require the inclusion by the participant of roughly one and one-half to two and one-laalf times more income than do the Table I rates. The disparity is much greater for ages over 70.

104. I.R.C. \& 79(b)(3); Treas. Reg. \& 1.79-2(d) (1966).

105. I.R.C. \& 262; Rev. Rul. 56-634, 1956-2 C.B. 291.

106. I.R.C. § 1348(b)(1)(A). See Treas. Reg. § 1.1348-3(a)(1) (1970), pertaining to the pre1977 concept of earned income, which was less expansive than the concept of personal service income. See also Private Letter Ruling 7913046.

107. I.R.C. \& 3401(a)(12)(A), (B); Treas. Reg. \& 31.3401(a)(12)-1(a), (b) (1957). This conforms with the exclusion froin withholding of employer-paid group-term life insurance premiums. I.R.C. \& 3401(a)(14); Treas. Reg. § 31.3401(a)(14)-1 (1977).

108. I.R.C. \& 72(m)(3)(B).

109. Rev. Rul. 68-390, 1968-2 C.B. 175. 


\section{Distributions}

\section{A. Non-Death Benefit Distributions.}

In the case of a life insurance policy that is utilized in part to fund retirement benefits (that is, annuitized), eitler the benefits or the contract itself may be distributed to the employee.

1. Distribution of the Policy Itself. Generally, the distribution of an annuity contract does not result in income to the employee unless the contract has a cash surrender value and is in fact surrendered. ${ }^{110}$

If, however, the contract . . . is a retirement mcome, endowment, or other life insurance contract . . . the entire cash value of such contract at the time of distribution must be imcluded in the distributee's income . . . except to the extent that, within 60 days after the distribution of such contract, all or any portion of such value is irrevocably converted into a contract under which no part of any proceeds payable on death ... would be excludable under section 101(a) ..... ${ }^{111}$

In addition, "within sucl 60 days sucli contract is also made nontransferable"112 if it is not already nontransferable. Under section 101(a) life insurance proceeds are generally excluded from gross mcome. Accordingly, the distribution of a life insurance policy froin a qualified plan will result in the recognition of income to the distributee in an anount cqual to the casli surrender value of the policy unless, within 60 days after distribution, the policy is made nontransferable and is irrevocably converted into a policy that does not provide life imsurance protection. A failure to so convert the contract will not, in itself, cause the trust and the plan of which it is a part to fail to qualify. ${ }^{113}$

In Evans v. Commissioner ${ }^{114}$ the Tax Court considered the distribution froin a qualified trust of eight contracts, each of which had a life insurance element and an annuity element when originally issued. The ainount payable at death was the larger of the face amount or the cash surrender value. As to seven of the contracts, the cash surrender value exceeded the face amount at the tinne of distribution. The court held that for purposes of regulations section 1.402(a)-1(a)(2) these seven contracts were not insurance contracts when distributed. The eighth contract was found to be an insurance contract because it had a face value in excess of its cash surrender value.

110. Treas. Reg. \& 1.402(a)-1(a)(2) (1960).

111. Id.

112. Id. See I.R.C. \& 72(h).

113. Rev. Rul. 60-84, 1960-1 C.B. 159.

114. 56 T.C. 1142 (1971), gov't's appeal dismissed (nolle pros.) (3d Cir. 1972). 
2. Income Taxation of Retirement Benefits. Whether the policy itself is distributed to the employee or the trust retams the policy and acts as a conduit for the benefits, the employee is entitled to receive, tax free, that portion of the retirement benefits that he actually or constructively paid for with after-tax dollars. Regulations section 1.72-16(b)(4) provides that the amount which is imcludible in the gross income of the employce with respect to insurance purchased by the plan (the P.S. 58 cost) "shall be considered as premiums or other consideration paid . . . by the employee [but] only with respect to any benefits attributable to the contract .. . providing the life insurance protection." 115

"[R]etirement benefits and life insurance will be considered part of a single separate prograin of imterrelated contributions and benefits [that is, a single contract with respect to which the participant's costs may be recovered] to the extent they are provided under retirement income, endowment, or other contracts providing life insurance protection."116 Thus, in the case of a whole life policy providing retirenent or endowment mcome, the entire amount mcluded in the taxable imcoine of the employee (not inerely the tax paid) may be recovered tax free from the retirement benefits received under the policy, as may any premiums paid out of employec contributions. ${ }^{117}$ No amount is recoverable with respect to a contract of pure term msurance, in that such a contract does not fund retirement benefits. ${ }^{118}$ This dichotomy is somcwhat illogical in that, in the case of a whole life policy, the amount mcluded in the mcome of the cmployee at the time that contributions or trust earnings are applied to purchase life insurance presumably represents the "pure" insurance cost-that is, the equivalent cost of term insurance-and such pure msurance protection is currently consumed and therefore does not fund a retireinent benefit. However, the recovery of these premium costs from retirement or endowment benefits under whole life policies conforms with the treatment of such contracts purchased outside of qualified plans.

\section{B. Gift Taxation of Transfers of Future Retirement Benefits.}

Section 2517, which provides special rules concerning the gift tax consequences of an election by an employee whereby an annuity or other payinent from a qualified plan will become payable to any beneficiary after the employee's deatli, is equally apphicable when such ben-

115. Treas. Reg. \& 1.72-16(b)(4) (1963).

116. Treas. Reg. $\$ 1.72-2$ (a)(3)(ii)(d) (1960).

117. Treas. Reg. $\$ 1.72-1$ (1960).

118. Treas. Reg. § 1.72-2(a)(3)(iv), ex. 6 (1960). 
efits are funded through a life insurance contract. The revocable designation of a beneficiary is, of course, not a completed gift and not taxable. An irrevocable designation, either by affirmative action or when the employee permits a designation to becoine irrevocable under the terms of the plan, is deemed by section 2517(a) not to be a transfer for purposes of the gift tax at the time of the exercise or nonexercise of the option, or at the time of the termination of the plan if earher. However, under section 2517(b), this exclusion is not available to the extent that the annuity or other payment is attributable to payments or contributions of the employee. ${ }^{119}$ An irrevocable beneficiary designation made with respect to benefits attributable to such employee contributions is a coinpleted, taxable gift which, because it is a future interest, ${ }^{120}$ is not eligible for the $\$ 3,000$ annual exclusion provided by section 2503(b).

\section{Death Benefit Distributions.}

1. Income Taxation of Death Benefits. The general rule of section 101(a)(1), which excludes froin gross income "amounts received . . . under a hfe imsurance contract . . paid by reason of the death of the insured," 121 does not apply to a life insurance contract purchased by a qualified plan if the einployee either paid the cost of the insurance or was taxable on the cost of the insurance, ${ }^{122}$ as will normally be the case when the benefit is payable to the employee's estate or beneficiary. Rather, the reserve accumulation or cash value, if any, of such a policy is presumed to lave funded the pension or other deferred benefits under the plan.

The portion of the proceeds paid upon the death of the insured employee which is equal to the cash value immediately before death is not excludable from gross income under section 101(a). The remaiming portion, if any ... - that is, the amount in excess of the cash value-constitutes current insurance protection and is excludable under section 101(a). ${ }^{123}$

The portion of the proceeds equal to the cash value is taxed, together witl other distributions from the plan, in accordance with sections 402 and 72. Part or all of this amount will be excluded froin the

119. It is not specified whether the reference in I.R.C. $\$ 2517(\mathrm{~b})$ to "contributions unade by the employee" is limited to actual employee contributions or includes contributions constructively made by the employee by virtue of amounts includible in his income (the P.S. 58 cost). The former conclusion is the more likely, as the latter would be beyond the literal language of the Code and regulations. Cf. Treas. Reg. $\$ 20.2039-2(b)(4)$, ex. 3 (1958) (contributions made by employee included contributions constructively made by employer by virtue of his employment where section 2039 specified that any contribution by employer shall be considered made by cmployee if made by reason of his employment).

120. Treas. Reg. $\$ 25.2517-1$ (a)(1) (1961).

121. I.R.C. \& 101(a)(1).

122. Treas. Reg. $\S \S 1.101-1(a)(2)(i)(1957), .402(a)-1(a)(4)(1956), .72-16(c)(1)(1963)$.

123. Treas. Reg. $\S 1.72-16$ (c)(2)(ii) (1963). 
income of the recipient to the extent that the employees' death benefit exclusion of section 101(b) is applicable ${ }^{124}$ and to the extent the amount is attributable to contributions of the employee. The P.S. 58 cost, which was included in the income of the employee, is deemed to have been a contribution of the employee for this purpose. ${ }^{125}$

The portion of the distribution in excess of the cash value is excluded from income taxation under section 101(a). Section 101(d), which, in the case of insurance proceeds paid at a date later than death, requires proration between the insurance proceeds and an interest element, and which provides an additional $\$ 1,000$ per year exclusion with respect to the interest element for the insured's surviving spouse, is only applicable to that portion of the benefits attributable to the amount excludable under section 101(a). ${ }^{126}$

2. Estate Taxation of Death Benefits. For estate tax purposes, death benefits attributable to life insurance proceeds are treated in the same way as are other death benefits payable from a qualified plan. ${ }^{127}$ Thus, under section 2039(c), benefits other than those attributable to contributions made by the decedent that are payable to any beneficiary other than the decedent's estate or for the benefit of the estate are excluded from the gross estate provided that they do not constitute all or part of a luinp sum distribution ${ }^{128}$ with respect to which ten-year averaging is elected. Under section 402(e)(1) a lump sum distribution is entitled to special income tax treatment utilizing ten-year forward averaging and employing an exclusion for a minimum distribution allowance. The same distribution may not receive both this special income tax treatment and estate tax exclusion under section 2039(c)..$^{129}$

The section 2039(c) exclusion is available despite the fact that the employee inay have had the right to change the beneficiary of the insurance, as well as other rights with respect to the policy, and thus pos-

124. Treas. Reg. § 1.72-16(c)(2)(iii) (1963). Generally, distributions from qualified trusts on behalf of common law employees will qualify for the employees' death benefit exclusion, which is limited to $\$ 5,000$ with respect to the death of any one employee. I.R.C. $\$ 101(\mathrm{~b})$.

125. Treas. Reg. $\S \S 1.72-16(b)(4)(1963),-16(c)(3)$, ex. I (1963).

126. Treas. Reg. \& 1.72-16(c)(2)(iv) (1963).

127. See generally Nasuti, How to Coordinate Income and Estate Tax Planning for Qualified Plan Distributions, 49 J. TAx. 194 (1978).

128. The term "Iump sum distribution" is described in I.R.C. $\$ 402(\mathrm{e})(4)$; for purposes of I.R.C. $\$ 2039(\mathrm{c})$ the next-to-last sentence of I.R.C. $\$ 402(\mathrm{e})(4)(\mathrm{A})$ is disregarded. I.R.C. $\S 2039(\mathrm{f})(1)$.

129. The Revenue Act of 1978, Pub. L. No. 95-600, § 142(b), 92 Stat. 2796 (codified at I.R.C. $\S 2039(f)(2)$ ) applicable with respect to estates of decedents dying after 1978, provides that the I.R.C. $\$ 2039$ (c) exclusion will be available even with respect to a lump sum distribution so long as the recipient irrevocably elects to forego ten-year averaging. 
sessed at his death "incidents of ownership" with respect to the policy that would have caused inclusion in his gross estate under section 2042(2). In effect, section 2039(c) overrides section 2042. ${ }^{130}$

In the case of a contributory plan, no exclusion is permitted under section 2039(c) for that part of any distribution that is attributable to contributions inade by the einployee, ${ }^{131}$ including a distribution of life insurance proceeds purchased with einployee contributions. ${ }^{132}$ However, the ainount required to be included in the incoine of the employee with respect to earnings or employer contributions applied to purchase life insurance (the P.S. 58 cost) is not considered an employee contribution for this purpose. ${ }^{133}$

\section{Coordination of Income and Estate Tax Planning for Death Benefit Distributions.}

A death benefit distribution of life insurance proceeds from a qualified plan offers the opportunity for exclusion froin both estate and incoune taxation; this is one of the important advantages of funding a qualified plan with life insurance. In order to qualify for estate tax exclusion it is necessary that the recipient forego ten-year forward averaging for full taxation of the distribution as ordinary income. However, this consideration is irrelevant as to the excess of the life insurance proceeds over the cash value of the policy, in that this portion of the distribution is excluded under section 101(a) and will not be subject to incorne taxation in any event. If the amount excludable under section 101(a) is large in relation to the total amount distributable, a relatively small incoine tax will be payable on the distribution in any case, and it may be desirable to give up ten-year forward averaging incoine tax treatment in favor of estate tax exclusion. A countervailing consideration is that where the total taxable amount is small, forward averaging will result in a very small income tax burden.

1. Payment to the Trust. Ten-year forward averaging is only available if the distribution qualifies as a lunp sum distribution, which in turn requires that the balance to the credit of the decedent in the trust be distributed within one taxable year of the recipient. ${ }^{134}$ In order to retain flexibility it is advisable to have the insurance proceeds payable to the trust rather than directly to the beneficiary so that if lump

130. Treas. Reg. $\S 20.2039-2$ (b), ex. 3 (1958); Rev. Rul. 67-371, 1967-2 C.B. 329.

131. Treas. Reg. $\$ 20.2039-2$ (c)(1) (1958).

132. Rev. Rul. 70-211, 1970-1 C.B. 190.

133. See Treas. Reg. \& 20.2039-2(b), ex. 3 (1958).

134. I.R.C. \& 402(e)(4)(A). 
sum distribution treatment is desired the trustee can see to it that all benefits are paid within the same taxable year of the recipient. ${ }^{135}$

Regulations section 1.72-16(b)(1) provides that the proceeds of a life insurance contract purchased by a qualified plan will be considered "payable .... mdirectly to a participant ... or to a beneficiary of such participant," 136 and thus be governed as to the taxability of the cost of life imsurance protection by regulations section 1.72-16(b), where such proceeds "are payable to the trustee but under the terms of the plan the trustee is required to pay over all of such proceeds to the beneficiary."137 Although not specifically stated, regulations section 1.72-16(c), pertaining to the income taxation of msurance proceeds, should also be applicable in such circumstances. Therefore, the characterization of the payment as insurance proceeds, with the concommitant exclusion of the excess of the proceeds over the cash value under section 101(a), should also result.

It is not clear whether payment to the beneficiary as part of an annuity or in imstallment payments, rather than in a lump sum, will cause proceeds to lose their characterization as imsurance for imcome tax purposes. Placement of the proceeds im a segregated account would strengthen the argument that they do not. Even if not placed in a segregated account, imsurance proceeds ought to retam their tax free character upon receipt by the beneficiary, both in view of regulations section 1.72-16(b)(1) and by analogy to the treatment of distributions attributable to employee contributions.

2. Uncertainties Concerning the Section 101(a) Exclusion. As previously discussed, ${ }^{138}$ lump sum distribution treatment is preconditioned on the entire balance to the credit of the employee being paid within one taxable year of the recipient. ${ }^{139}$ However, there is a lack of coordination between the exclusion for life insurance proceeds and the lump sum distribution rules, and it is not specified whether "the balance to the credit" of the employee includes the amount excludable under section 101(a); the prudent assumption would be that it does. ${ }^{140}$

135. See, e.g., Blyler v. Commissioner, 67 T.C. 878 (1977), in which a life insurance policy was distributed to a terminated employee in one taxable year and the balance to his credit in the next, thus foreclosing lump sum distribution treatment.

136. Treas. Reg. § 1.72-16(b)(1)(ii) (1963).

137. Id.

138. See text accompanying note 135 supra.

139. I.R.C. \& 402(e)(4)(A); Proposed Treas. Reg. $§ 1.402(\mathrm{e})-2(\mathrm{~d})(1)(\mathrm{i})$.

140. But see Proposed Treas. Reg. $\$ 1.402(\mathrm{e})-2(\mathrm{~d})(1)($ viii), which states that "[t]he balance to the credit of the employee is includible in the gross income of the recipient . . .," a statement which is incorrect if the balance to the credit of the employee imcludes the amount excludable under section 101(a). 
For purposes of calculating the special separate tax on luinp sum distributions the "total taxable annount" is defined by reference to the ainount of the luinp suin distribution (which is apparently equal to the balance to the credit of the decedent), with no subtraction specified for a1nounts excludable under section 101(a). ${ }^{141}$ This raises three possibilities. The first is that the section 101(a) exclusion is inapplicable for purposes of calculating the special separate tax on lump sum distributions. This is unlikely, since "[f]or the rules apphicable to the amounts payable by reason of the death of an employee . . ."142 regulations section 1.402(a)-1(a)(4) cross-references to regulations section 1.72-16(c), which in turn invokes section 101(a). ${ }^{143}$ The second possibility is that the ainount subject to the section 101(a) exclusion is not part of the balance to the credit of the einployee who, after all, could never have received it. In this event this amount could be distributed in a taxable year of the recipient different from that in which other distributions are made without foreclosing luinp suin distribution treatment. The lack of coordination appears to be a drafting oversight, and the third and most likely possibility is that the amount subject to the section 101(a) exclusion is part of the balance to the credit of the einployee, but is not part of the total taxable amount.

3. Split Payment. Although not common, it is possible to have the insurer pay the amount subject to the section 101(a) exclusion dircctly to the beneficiary and pay the balance of the insurance proceeds to the trust. ${ }^{144}$ It is not clear that this procedure will achieve its intended purpose. In that it is not possible to identify specifically which dollars are taxable and which are not, it may be necessary to prorate each payinent between those two eleinents.

Assuming that the separation will be recognized for tax purposes, and that proration is not required, split payenent would have the advantage of placing the tax free portion of the distribution in the hands of the beneficiary immediately while deferring tax on the balance. It would not be prudent if lump sum distribution treatment is sought unless it should become clear that the annount eligible for the section 101(a) exclusion is not part of the balance to the credit of the employee.

141. I.R.C. § 402(e)(4)(D); Proposed Treas. Reg. § 1.402(e)-2(d)(2)(i).

142. Treas. Reg. \& 1.402(a)-1(a)(4) (1956).

143. Note, however, that Treas. Reg. $\S 1.402$ (a) has not been amended to reflect ERISA's introduction of the special separate tax into the Internal Revenue Code.

144. See Rev. Rul. 59-401, 1959-2 C.B. 121, which held that the payment of benefits directly to the beneficiary did not affect application of I.R.C. $\$ \S 101(b), 402(a)(2)$ and 2039(c)(1). 


\section{H.R. 10 Plans: Special Considerations}

An H.R. 10 (or Keogh) plan is a qualified pension or profit-sharing plan for the benefit of self-employed individuals or the owners and employees of unincorporated businesses. The tax consequences of the acquisition of life insurance by such a plan are generally the same as in the case of a corporate plan, subject to certam special exceptions.

\section{A. Funding.}

A pension or profit-sharing H.R. 10 plan will not qualify "if the plan provides only such retirement benefits as are furnished through the purchase of ordinary life insurance contracts, or similar life insurance contracts providing death benefits greater than 100 times the amount of the monthly retirement income available under such contracts." 145 This is a restatement of the same general rule, implementing the restriction that life insurance be "incidental," as is applicable to corporate plans.

1. Level-Premium Insurance Contracts. In order to permit an H.R. 10 plan to purchase level-premium annuity, endowment or life insurance contracts for the benefit of an owner-employee ${ }^{146}$ without the danger that the contracts will have to be cancelled in a subsequent year if the owner-employee's earned income is too low to permit contributions sufficient to keep the policies in force, a special three-year averaging method is provided. ${ }^{147}$ Contributions that the plan expressly requires to be applied, either directly or indirectly, to pay such premiums will not constitute excess contributions if all of the proceeds of the contracts are payable to the owner-employee or his beneficiary, ${ }^{148}$ and the amount of contributions used to pay such premiums does not exceed the average of the amounts deductible by the owner-employee

145. Rev. Rul. 65-25, 1965-1 C.B. 173, 174. See also Rev. Rul. 70-28, 1970-1 C.B. 86.

146. There are three possible types of participants in an H.R. 10 plan: owner-employees, partner-employees, and common law employees. See generally Lamon, (ERISA)-H.R 10 PlansTaxation of Distributions, 316 TAX MANAGEMENT PortFolio A-1 to A-3 (1977). An owner-employee is the sole proprietor of an unincorporated trade or business or a partner who owns more than a $10 \%$ interest in either the capital or profits of a partnership. I.R.C. $\$ 401$ (c)(3). "Partnereinployee" is not defined in the Internal Revenue Code, but is generally defined in plans as a partner who is not an owner-einployee because he owns ten percent or less of the capital and profits interest in a partnership. Lamon, supra at A-2. "Common law employee" similarly is not defined in the Code or regulations. The term refers to persons who are ordinarily thought of as einployees in the common sense of the word, i.e, employees who do not have an ownership interest in the business. Id. A-2-A-3.

147. I.R.C. $\S \S 401$ (d)(5), 401(e)(3) (last sentence); H.R. REP. No. 807, 93d Cong., 2d Sess. 117 (1974).

148. Treas. Reg. § 1.401-13(c)(3) (1963). 
based on his earned incoine for the three preceding taxable years for which the owner-employee had earned imcome, ${ }^{149}$ or the three years prior to the date on which the last insurance contract was issued, whichever is higher. ${ }^{150}$ If this exception is utilized the maximum contribution on behalf of an owner-einployee, under all plans in which he participates as an owner-employee, inay not exceed $\$ 7,500 .^{151}$ Amounts allocable to the purchase of life, accident, health and other insurance, including waivers of premiums, count towards this limitation. ${ }^{152}$ However, voluntary owner-employee contributions may be used to purchase life insurance without regard to this limitation..$^{153}$

The limitation on contributions on behalf of self-employed persons of section 404(e), to which the preceding discussion pertains, is the lesser of $\$ 7,500$ or fifteen percent of earned income. This limitation is inapplicable to defined benefit H.R. 10 plans, ${ }^{154}$ which inust ineet special requirements set forth in section $401(j)$.

In addition to the limitations on contributions discussed above, section 415(c) limits the permissible aunual addition for defined contribution plans. ${ }^{155}$ Section 415 (c)(7) provides that the twenty-five percent of compensation limitation on the permissible annual addition found in section $415(\mathrm{c})(1)(B)$ is inapplicable to contributions to pay premiums on level-premium annuity, endowment or life insurance contracts benefiting owner-employees so long as "the annual addition . . . with respect to the participant for such year consists solely of such contribution, and . . . the participant is not an active participant at any time during sucll year in a defined benefit plan maintained by the employer." 156 Provided that these conditions are met the three-year averaging inethod of section 401(e) and regulations section 1.401-13(c), discussed above, may be utilized.

2. Other Insurance Contracts. Other than for purposes of the three-year averaging method, any contribution on behalf of an owneremployee allocated to the purchase of life insurance is disregarded in

149. Treas. Reg. \& 1.401-13(c)(4)(i) (1963). If the owner-employee has not derived taxable mcome from the busmess for at least three taxable years preceding the date on which the contract was entered into, then only those taxable years in which the owner-employee was engaged in the business and derived earned income therefroin are taken into account. Id.

150. Rev. Rul. 65-200, 1965-2 C.B. 141.

151. I.R.C. $\$ 401(\mathrm{e})$.

152. Treas. Reg. \& 1.401-13(c)(l)(ii) (1963).

153. Rev. Rul. 69-399, 1969-2 C.B. 99.

154. I.R.C. $\$ 401(j)(6)$.

155. The term "annual addition" is defined in I.R.C. $\$ 415(c)(2)$. See text accompanying note 80 supra; see generally 1 Pens. Plan Guide (CCH) II 3671-73 (1977).

156. I.R.C. $\& 415(\mathrm{c})(7)(\mathrm{A})$, (B). 
applying the limitation on contributions. ${ }^{157}$ The P.S. 58 cost is deemed to be the allocable amount. ${ }^{158}$

\section{B. Contributions.}

Treatment of a self-employed person with respect to contributions allocable to the cost of life insurance for his benefit is consistent with the treatment of other participants under an H.R. 10 plan and all participants under a corporate plan. While such other participants must include in income the P.S. 58 cost of insurance protection provided for them, self-employed persons need not make such an inclusion but are denied a deduction for this amount, ${ }^{159}$ which yields the same ultimate tax result. If, under a trusted plan, trust earnings are applied to the paynent of life insurance premiums, the self-employed person must include the cost of the insurance protection in his income. ${ }^{160}$

\section{Distributions.}

1. Non-Death Benefit Distributions. Non-death benefit distributions under an H.R. 10 plan are treated in the same way as such distributions under a corporate plan, except that an owner-einployee may not recover the P.S. 58 cost of the insurance tax free as may other participants (including self-employed persons who are not owner-employees). This is despite the fact that such cost was nondeductible when incurred. ${ }^{161}$

2. Gift Taxation of Transfers. The gift tax exclusion of section 2517 , which provides that an irrevocable designation of a beneficiary of an annuity or other payment from a qualified plan will not be treated as a transfer for purposes of the gift tax, was extended to designations under H.R. 10 plans by the Tax Reform Act of $1976 .{ }^{162}$ For a common law einployee, the exclusion applies only to contributions made by the eniployer; for self-employed persons, contributions are deemed to have been made by an employer to the extent that they were deductible when made. ${ }^{163}$ In view of the fact that contributions to an H.R. 10 plan on behalf of a self-employed person that are allocable to the purchase

157. I.R.C. $\S 4972(b)(1)$; Treas. Reg. $\S \S 1.401-13(b)(1)(i i)(1963), .404(e)-1(f)(1963)$, -12(i)(2)(i)(1963).

158. Treas. Reg. $\$ 81.404(\mathrm{e})-1(\mathrm{f})(1963), .72-16(\mathrm{~b})$ (1963).

159. I.R.C. $\$ 404(\mathrm{e})(3)$; Treas. Reg. $\$ 1.404(\mathrm{e})-1(\mathrm{f})$ (1963); Proposed Treas. Reg. $\$ 1.404(\mathrm{e})-$ $1 \mathrm{~A}(\mathrm{~g})$.

160. Treas. Reg. \& 1.72-16(b)(2) (1963).

161. I.R.C. $\S 72(\mathrm{~m})(2) ;$ Treas. Reg. $\S 1.72-16(\mathrm{~b})(4)$ (1963); Proposed Treas. Reg. $\S 1.72-17 \mathrm{~A}(\mathrm{c})$.

162. Pub. L. No. $94-455,90$ Stat. 1895 (codified at 1.R.C. $\$ 2039$ (c)(4)(B)).

163. I.R.C. $\$ 2517$ (b) (last sentence). 
of pure insurance (the P.S. 58 cost) are not deductible, the section 2517 exclusion is inapplicable to benefits attributable to such costs.

3. Death Benefit Distributions-Income Taxation. Deatlı benefits payable from a life insurance policy held by an H.R. 10 plan are subject to incoine taxation in the same way as insurance benefits from a corporate plan, witli two exceptions. First, the $\$ 5,000$ employees' death benefit exclusion of section 101(b) is not available to the beneficiary of a self-employed person. ${ }^{164}$ Second, simce the P.S. 58 cost is not treated as consideration paid by an owner-einployee, the beneficiaries of owner-einployees (but not of other self-employed persons or common law employees) ${ }^{165}$ may not exclude from income the portion of the cash value of the insurance policy deemed attributable to such costs.

4. Death Benefit Distributions-Estate Taxation. Life insurancefunded death benefits from an H.R. 10 plan are also treated for estate tax purposes in generally the same way as benefits from a corporate plan. The Tax Reform Act of $1976^{166}$ extended the section 2039(c) estate tax exclusion to benefits payable with respect to self-employed persons under an H.R. 10 plan, subject to the same preconditions applicable to corporate plans. ${ }^{167}$ In the case of an employee the exclu.sion is only available with respect to benefits attributable to employer contributions. Similarly, in the case of the self-employed, the exclusion is only available with respect to benefits attributable to contributions that were deductible when made. ${ }^{168}$ In that amounts allocable to the purchase of life insurance for a self-employed participant im an H.R. 10 plan are not deductible, life insurance proceeds payable with respect to such a person cannot qualify for the section 2039(c) estate tax exclusion.

\section{Comparison Between Life Insurance in a Qualified Plan aNd Life Insurance in a Section 79 Plan}

Pure life insurance offers a unique opportunity to spread the insured's risk of untimely death among the group insured. There is no other investment that is a substitute for it, and the question of whether it should be in a qualified plan presupposes that it is a worthwhile ex-

164. Treas. Reg. \& 1.101-2(f)(1) (1957).

165. See text accompanying note 125 supra.

166. Pub. L. No. 94-455, 90 Stat. 1895 (codified at I.R.C. \& 2039(c)(2)).

167. See text accompanying notes $127-33$ supra.

168. I.R.C. \$ 2039(c) (second to last sentence). 
pense. From the point of view of an employer, an alternative to providing employees with either term or permanent life msurance protection under a qualified plan is to provide it under a plan that complies with section 79 .

\section{A. Group-Term (Section 79) Insurance Generally.}

Section 79(a) provides that

[t]here shall be included in the gross income of an employee . . the cost of group-term life insurance on his life provided ... under a policy . . . carried . . . by his employer . . . but only to the extent that such cost exceeds the sum of - (1) a cost of $\$ 50,000$ of such insurance, and (2) the amount (if any) paid by the employee toward the purchase of such insurance. ${ }^{169}$

Thus, the cost of the first $\$ 50,000$ of employer-provided group-term life insurance under a plan in compliance with section 79 is entirely excluded from the income of the employee. ${ }^{170}$ Furthermore, under section 79(c) the amount to be included in the employee's imcome with respect to group-term insurance in excess of $\$ 50,000$ is determined on the basis of a uniform premium table prescribed by regulations section 1.79-3(d)(2), Table I (Table I rates). Unlike the P.S. 58 rates, which prescribe the amount to be included in the income of the employee with respect to insurance protection provided under a qualified plan, the Table I rates are in five-year age brackets. More importantly, the P.S. 58 rates require the inclusion of roughly one and one-half to two and one-half timies more income than do the Table I rates, and the disparity is inuch greater for ages over seventy.

A group-term life insurance program eligible for the benefits of section 79 is subject to certain coverage and nondiscrimination requirements, but they are far less stringent than those imposed on qualified plans. The basic restriction is that a group of at least ten full-time employees must be covered. ${ }^{171}$ For this purpose a " 'group of employees' is all employees of an employer, or less than all employees if membership in the group is determined solely on the basis of age, marital status, or factors related to employment," such as compensation, duties performed or union membership. ${ }^{172}$ Similarly, the amount of insurance nust be based on factors that preclude mdividual selection, such

169. 1.R.C. $\$ 79(a)$.

170. Id.

171. Treas. Reg. $\S 1.79-1(c)(1)(1979)$. Under I.R.C. $\$ 125$, enacted by the Revenue Act of 1978, Pub. L. No. 95-600, $§ 134$ (a), 92 Stat. 2783 (1978), a cafeteria plan, as defined by I.R.C. $\S 125$ (d), may not discriminate in favor of highly compensated participants. Group-term life insurance provided under a cafeteria plan is subject to this restrictiou.

172. $I d$. 
as age, years of service, compensation or position. ${ }^{173}$

If the employer does not have at least ten employees the plan may still qualify if it covers all insurable full-time employees and otherwise precludes imdividual selection. ${ }^{174}$ Individual selection in this case will be deeined precluded if the anount of protection is computed either as a uniform percentage of salary or on the basis of coverage brackets established by an insurer under which no bracket exceeds two and onehalf times the next lower bracket and the lowest bracket is at least ten percent of the highest bracket. In addition, evidence of insurability may be a factor affecting either the employee's eligibility for insurance or the aunount of insurance provided only if such eligibility or amount of insurance is determined solely on the basis of a inedical questionnaire completed by the employee and a incdical examination is not required. ${ }^{175}$

Although not specifically permitted by the Internal Revenue Code, it is possible to have section 79 treatment with respect to the pure insurance portion of a policy that provides permanent protection. This is solnetimes referred to as "group-permanent" insurance. Such a policy will not qualify unless:

(i) The policy or the employer designates in writing the part of the death benefit provided to each employee that is group-term life insurance;

(ii) The part of the death benefit that is . . . designated as the groupterm life insurance benefit . . . is not less than the difference between the total death benefit provided under the policy and the employee's dcemed death benefit . . . at the end of the policy year . . . ; (iii) Employces nay elect to decline or drop the permanent benefit; and

(iv) The death benefit designated as group-term life insurance that is provided to any employee is not reduced because of that employee's election to decline or drop the permanent benefit. ${ }^{176}$

The cost of the permanent benefits, reduced by the amount paid for sucli benefits by the employee, is included in the employee's income. ${ }^{177}$

\section{B. Coverage and Nondiscrimination.}

Under sections 401(a)(3) and 410 a qualified plan inust cover a broad cross-section of an einployer's employees. Generally, either sev-

173. Treas. Reg. § 1.79-1(a)(4) (1979).

174. Treas. Reg. \& 1.79-1(c)(2) (1979).

175. Id.

176. Treas. Reg. $\S 1.79-1(b)(1)(1979)$. The term "deemed death benefit" is defined in Treas. Reg. \& 1.79-1(d)(3) (1979).

177. Treas. Reg. $\$ 1.79-1$ (d) (1979) (setting forth a formula for determining the cost of permanent benefits). See Rev. Proc. 79-29, 1979-22 I.R.B. 24, which establishes a procedure for determining the cost of permanent benefits and the deemed death benefit provided under life insurance policies that include both group-term life insurance and permanent benefits. 
enty percent or more of all employees must be covered or eighty percent or more of eligible employees may be covered if at least seventy percent of all employees are eligible. ${ }^{178}$ Under section 401(a)(4) the contributions or benefits provided under a qualified plan may not discriminate in favor of employees who are officers, shareholders or highly compensated. Thus, qualified plans are subject to stringent and complex rules concerning both coverage and nondiscrimination.

The coverage and nondiscrimination restrictions under section $79^{179}$ are far less difficult to meet. Therefore, section 79 is more adaptable: it may be used to reward a selected number of key employees, who are frequently also highly compensated and thus place greater importance on tax-favored benefits. Furthermore, it is generally possible to give highly compensated employees disproportionally more insurance protection than other covered employees, something that is difficult to accomplislı under a qualified plan. Also, there is no upper limit (other than the requirement that compensation be reasonable) to the amount of msurance that may be provided under a section 79 plan, as there is under a qualified plan.

\section{Current Income Taxation.}

A principal distmction between life insurance provided under a qualified plan and group-term life insurance entitled to the benefits of section 79 is that, as to the former, all premiums paid with respect to the pure insurance element must be included in the income of the employee in accordance with the P.S. 58 rates; as to the latter, only the premiums with respect to insurance protection in excess of $\$ 50,000$ are included in the income of the employee, and those only in accordance witll the less onerous Table I rates. ${ }^{180}$ Thus, section 79 resnlts in a substantially lower out-of-pocket cost to the employee for pure insurance protection.

In the case of perinanent insurance, the result is partially reversed. As to the pure insurance element, the treatment described in the preceding paragrapli remains applicable. However, a qualified plan has considerable flexibility in the purchase of whole life policies, while such policies may not be acquired by a section 79 plan unless the very specific requirements discussed above are met. ${ }^{181}$ More importantly, the

178. I.R.C. $\$ 410(\mathrm{~b})(1)(\mathrm{A})$.

179. See text accompanying notes 169-74 supra.

180. See text accompanying notes 98-103 supra. The P.S. 58 rates require the inclusion by the participant of roughly one and one-half to two and one-half times more income than do the Table I rates, and the multiple is much higher for participants over age 70 .

181. See text accoinpanying notes 176-77 supra. 
cost of the investment portion of permanent insurance is not currently taxable to the employee under the qualified plan, while that entire amount is fully includible in the incoine of the employee under the section 79 plan. Thus, the qualified plan can normally provide permanent protection with a lower current after-tax cost to the employee.

\section{Income Taxation of Retirement Benefits.}

If pure term insurance is provided, under either a qualified plan or a section 79 plan, no benefits will be payable other than death benefits. If, in the alternative, the qualified plan acquires whole life insurance or the section 79 plan acquires group permanent imsurance, then the cash values may be utilized to provide retirement or other pre-death benefits. While there is no authority on poimt, it appears that under the section 79 plan the employee cannot recover the benefits derived from Table I premium payments, whether or not included in his incoine. In contrast, in the case of a qualified plan, the P.S. 58 costs that were included in the employee's income may be recovered tax free from predeath benefit distributions.

\section{E. Income Taxation of Death Benefits.}

Death benefits froin pure term insurance are fully excludible from incoine under section 101(a) whether the policy is provided under a qualified plan or a section 79 plan. In the case of a section 79 plan providing permanent benefits, the exclusion extends to the entire proceeds of the policy. However, in the case of permanent insurance provided by a qualified plan, only the excess of the proceeds over the cash value immediately before death is excludible; the balance is taxable to the recipient in accordance with the ordinary rules pertaining to distributions from qualified plans. ${ }^{182}$ This diclotomy reflects the difference in treatment at the time contributions were made-the qualified plan acquired permanent insurance protection with before-tax dollars, while the cost of such protection under the section 79 plan was included in the income of the employee.

\section{F. Estate Taxation of Death Benefits.}

As was discussed above, ${ }^{183}$ life insurance proceeds received froin a qualified plan inay, in addition to an income tax exclusion, receive a

182. See text accompanying notes 122-26 supra. Note that lump sum distribution treatment and ten-year forward averaging may be available with respect to the portion subject to income taxation.

183. See text accompanying notes 127-33 supra. 
complete estate tax exclusion under section 2039(c). The only prerequisite is that ten-year forward averaging income tax treatment not be elected; the employee may have retained until death incidents of ownership in the policy, including the right to change beneficiaries. No estate tax exclusion is available for insurance provided under a section 79 plan if the insured retained until death any incidents of ownership in the policy. If, however, the insured is willing to part with all incidents of ownership in the policy, including the right (if provided) to convert the group insurance to individual insurance upon the termination of employment, and is permitted to do so under state law, then he may eliminate from his estate the proceeds of a policy provided under a section 79 plan. The fact that he may terminate coverage under the group policy by terminating employment is not viewed as a sufficient mcident of ownership to require inclusion in the gross estate under section $2042 . .^{184}$

\section{G. Post-Retirement Coverage and Retired Lives Reserve.}

Although an einployer may not inake contributions to a qualified plan with respect to an employee who has retired, life insurance coverage may be continued by the plan for a participant after retirement. However, after approximately age sixty-five the P.S. 58 cost is relatively high, and the resultant tax may constitute an economic burden to the participant.

In contrast, under section 79(b), the cost of group-term life insurance, even for amounts in excess of $\$ 50,000$, is apparently not included in the incoine of the insured if he is no longer an employee of the employer and has either reached retirement age or become permanently disabled. This soinewhat unusual result ariscs because, prior to the enactment of section 79, einployer-provided group-term life insurance was treated by the regulations as entirely excludible from the income of the einployee. ${ }^{185}$ Section 79(a) is premised on the assumption that this treatinent was correct, and therefore is an inclusion provision; that is, it requires the inclusion in incorne of the cost of insurance in excess of $\$ 50,000$ rather than excluding from income the cost of insurance up to $\$ 50,000$. Section 79 (b) specifies the nonapplication of the inclusionary rule section 79(a). Therefore, no portion of the cost of group-term life insurance would appear includible in the income of the participant in the event that section 79(b) applies. Note, however, that under section

184. Rev. Rul. 69-54, 1969-1 C.B. 221, as modified by Rev. Rul. 72-307, 1972-1 C.B. 307.

185. See CoNF. Rep. No. 1149, 88th Cong., 2d Sess. (1964), reprinted in [1964] U.S. CoDE CONG. \& AD. NEwS 1940, 1958; S. REP. No. 830, 88th Cong., 2d Sess. (1964), reprinted in [1964] U.S. CODE CONG. \& AD. News 1673, 1717, 1876. 
61 and the concept of incoine as presently developed the value of employer-provided group-term life insurance would seem to constitute income to the einployee. ${ }^{186}$

It would be somewhat rare, although not impermissible, for an employer to continue life insurance coverage for an ex-employee in the absence of an obligation to do so. It is possible, and more common, for an employer to fund post-retirement life imsurance coverage in advance on a currently deductible basis by making contributions to a retired lives reserve, which is a fund for continuing coverage on retired einployees. ${ }^{187}$ Under Revenue Rulings $69-382^{188}$ and $73-599^{189}$ deductibility of contributions to such a reserve is subject to the following preconditions: (1) the balance in the reserve unust be held by the insurance coinpany for the sole purpose of providing coverage on active and retired einployees; (2) the contribution added to the reserve nay not exceed the amount necessary to allocate the cost of the insurance coverage over the working hives of the einployees involved; (3) the employer inust have no right to recapture any portion of the reserve so long as any active or retired einployee remaims ahve; and (4) contributions must be actuarially determined and nade on a level basis. ${ }^{190}$

A mechanisin similar to a retired hives reserve, but somewhat simpler, is also available: an employer's nonrefundable contribution to an employees' trust to provide group life insurance for both active and retired einployees is currently deductible under section 162 as an ordinary and necessary business expense. ${ }^{191}$

\section{H. Life Insurance and Unincorporated Businesses.}

Section 79 is inapplicable to insurance coverage for the self-employed. ${ }^{192}$ However, as was discussed above, self-employed persons are also denied a deduction for the P.S. 58 cost of life insurance provided under an H.R. 10 plan, and life insurance benefits paid from an H.R. 10 plan with respect to such persons are inehgible for the section 2039 (c) estate tax exclusion. Furthermore, owner-employees may not

186. See, e.g., Goldsmith v. United States, 586 F.2d 810 (Ct. Cl. 1978); Treas. Reg. \$ 1.612(d)(2)(ii)(1957). Treas. Reg. § 1.79-1(a)(3) (1966) and Proposed Treas. Reg. \& 1.79-1(f)(2) specify that, if I.R.C. $\$ 79$ is inapplicable, the amount includible in the employee's mcome is determined under I.R.C. \$61(a).

187. See generally Roberts, Retired Lives Reserve, 32 C.L.U.J. 31 (1978).

188. 1969-2 C.B. 28.

189. 1973-2 C.B. 41.

190. See also Rev. Rul. 77-92, 1977-1 C.B. 41, as to the inclusion in the incoine of the employer of a reserve recaptured by the employer.

191. Rev. Rul. 69-478, 1969-2 C.B. 29. See also Private Letter Ruling 7910064.

192. Treas. Reg. § 1.79-1(b)(2)(i) (1966); Treas. Reg. § 1.79-0 (1979). 
recover the P.S. 58 cost of life insurance incoine tax free from pre-death benefits paid. Therefore, life insurance is not in a substantial sense a tax-favored benefit for the self-employed. If life insurance is being considered for both the owners and the employees of an unincorporated business it may be realistic to disregard prospective self-einployed participants in analyzing the tax benefits.

\section{Other Aspects of Life Insurance In Qualified Plans}

Life insurance is the only inechanism available for providing an immediate substantial death benefit without accumulating investments and relying upon their earnings. Purchasing life insurance in a qualified plan gives rise to certain special tax benefits that were summarized above in the comparison with a section 79 plan. ${ }^{193}$ These include a possible estate tax exclusion under section 2039(c) and the opportumity to acquire the permanent element of whole life imsurance with beforetax dollars.

Under section 401(f) a quahified plan that is funded entirely through group msurance contracts is not required to have, and inay save the expense of, a trust. Since a plan funded entirely with ordinary whole life policies will not qualify, the pohcies must be "retirement income," "income endowment," "insurance annuity," or other contracts that develop cash value quickly. ${ }^{194}$ Under section $412(\mathrm{~h})(2)$ the minimum funding standards of section 412 do not apply to certain insurance contract plans described in section 412(i).

On the negative side, the cost of the pure insurance protection is currently taxed to the participant. In addition, placing life insurance in a qualified plan may provide some participants with more insurance than they need or wish to have. The amount expended for such insurance reduces amounts available to fund retirement benefits, and thus will reduce the amount of such benefits.

\section{A. Permanent Insurance in Qualified Plans.}

As discussed earher, ordinary (or whole) life insurance has, in effect, two separate and distinct components: a pure insurance element and an investment element. ${ }^{195}$ An ordinary life contract consists of term insurance that declines over the period of the contract, ultimately reaching zero, and an imvestment element that starts out small and, through additional contributions and earnings, ultimately reaches or

193. See text accompanying notes 178-91 supra.

194. See generally 1 PeNs. Plan GuIde (CCH) If 4367 (1975).

195. See notes 11-13 supra and accompanying text. 
exceeds the face amount of the contract. The two elements, taken together, result in the imsured always being certain of receiving no less than the face amount of the contract and therefore being "permanently" insured. However, he could be placed in a similar position by purchasing a declining term policy and establishing a program of regular investments in an appropriate amount together with the reinvestment of earnings thereon.

While a qualified plan can purchase permanent insurance with after-tax dollars, the special tax treatment accorded such insurance is of diminisleed value when the policy is owned by sucli a plan. The earnings on the investment portion of a whole life policy are subject to a very low rate of incoine taxation to the insurance company, which benefits the policy owner because it is reflected in lower premiun rates and larger casli value increases. In addition, policy dividends are not taxable to the owner of the policy until they exceed premiums paid. ${ }^{196}$ These are normally important considerations to a purcliaser of insurance. However, all of the earnings of a qualified plan are exempt from current taxation in any case, ${ }^{197}$ and the plan may be able to earn a higher rate of return with an alternative investment. In fact, life insurance companies themselves will frequently guarantee high returns on insured deposit administration contracts. ${ }^{198}$

A countervailing consideration is that the reserve allocated to a life insurance policy or aimuity held by a qualified plan is treated by the insurance company policy as a pension plan reserve under section 805(d), and the earnings on such a reserve are effectively exempt from current income taxation. ${ }^{199}$ Insurance companies will normally pass a portion of this saving through to the policy owner by crediting a higher rate of return on policies acquired by qualified plans.

\section{B. Other Considerations.}

There are certain economic advantages umque to life insurance. ${ }^{200}$

196. I.R.C. $\$ 72$.

197. I.R.C. \$ 501(a).

198. See Herman, Despite Critics' Sniping, Insurance Contracts That Guarantee Savers 8\%-9\% Become Popular, Wall St. J., Aug. 28, 1978, at 30, col. 1.

199. See generally 8 J. Mertens, Law of Federal Income Taxation Ch. 44A (rev, ed. 1978); Knickerbocker, Walker \& Levy, Life Insurance Companies-Taxable Income, $246 \mathrm{~T}_{\mathrm{AX}}$ Management Portfolio A-1 (1971).

200. But see Private Letter Ruling 7918095 (which holds that borrowing against a life insurance policy held by a quahified plan gives rise to unrelated debt-financed incoine subject to tax undcr I.R.C. \$ 514). See generally Miller, How to Sell Life Insurance in Existing Qualified Plans, 111 TRusts \& Estates 786 (1972); Morrison, Funding Slock Purchase Agreements with Insurance in Qualified Plans, 32 C.L.U.J. 40 (1978); Mulock, Controlled Target Plan: Maximum Life Insurance Under New Pension Law-Salable, and Unassailable, 29 C.L.U.J. 32 (1975); Shadur \& Wein- 
Utilization of whole life insurance fixes the cost of the annuity option at retirement at current annuity prices, which protects the insured against the possibility that the mortality rate, and thus the cost of an annuity, will increase. Insurance companies provide actuarial services without additional charge, and insurance agents sometimes provide substantial advisory and administrative services without a charge other than the commission they will earn by selling the insurance.

\section{CONCLUSION}

Life insurance is a unique asset, and its inclusion in employee benefit programs is very common. Placing life insurance in a qualified plan gives rise to certain special and complex tax consequences that should be carefully analyzed, together with related economic matters, in evaluating the advisability of this form of investment and the extent to which funds should be committed to it.

berg, Whole Life Insurance in Qualified Retirement Plans: Misfit or Magic?, 30 C.L.U.J. 24 (1976); Van Cleve, Life Insurance as a Funding Vehicle in Qualified Pension and Profit Sharing Plans, 24 C.L.U.J. 26 (1970). Shadur and Weinberg mathematically analyze the costs and benefits of whole life insurance assuming the borrowing of all cash values, and conclude that utilization of whole life insurance in a qualified plan "may, in fact, be the best buy in life insurance." Shadur \& Weinberg, supra at 24. 
